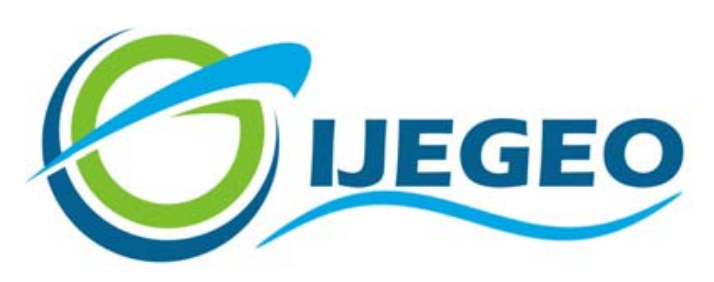

International Journal of Environment and Geoinformatics (IJEGEO) is an international, multidisciplinary, peer reviewed, open access journal.

\title{
Modelling of the Oil Spill in M/V LADY TUNA Accident and the Evaluation of the Response Operation in Simulated Condition with PISCES II
}

\section{Deniz AYDIN \& Murat Selçuk SOLMAZ}

\author{
Chief in Editor \\ Prof. Dr. Cem Gazioğlu \\ Co-Editor \\ Prof. Dr. Dursun Zafer Şeker, Prof. Dr. Şinasi Kaya, \\ Prof. Dr. Ayşegül Tanık and Assist. Prof. Dr. Volkan Demir
}

Editorial Committee (2019)

Assos. Prof. Dr. Abdullah Aksu (TR), Prof. Dr. Bedri Alpar (TR), Prof. Dr. Lale Balas (TR), Prof. Dr. Levent Bat (TR), Prof. Dr. Paul Bates (UK), Prof. Dr. Bülent Bayram (TR), Prof. Dr. Luis M. Botana (ES), Prof. Dr. Nuray Çağlar (TR), Prof. Dr. Sukanta Dash (IN), Dr. Soofia T. Elias (UK), Prof. Dr. A. Evren Erginal (TR), Assoc. Prof. Dr. Cüneyt Erenoğlu (TR), Dr. Dieter Fritsch (DE), Assos. Prof. Dr. Çiğdem Göksel (TR), Prof.Dr. Lena Halounova (CZ), Prof. Dr. Manik Kalubarme (IN), Dr. Hakan Kaya (TR), Assist. Prof. Dr. Serkan Kükrer (TR), Assoc. Prof. Dr. Maged Marghany (MY), Prof. Dr. Michael Meadows (ZA), Prof. Dr. Nebiye Musaoğlu (TR), Prof. Dr. Erhan Mutlu (TR), Prof. Dr. Masafumi Nakagawa (JP), Prof. Dr. Hasan Özdemir (TR), Prof. Dr. Chryssy Potsiou (GR), Prof. Dr. Erol Sarı (TR), Prof. Dr. Maria Paradiso (IT), Prof. Dr. Petros Patias (GR), Prof. Dr. Elif Sertel (TR), Prof. Dr. Nüket Sivri (TR), Assoc. Prof. Dr. Füsun Balık Şanlı (TR), Prof. Dr. Uğur Şanlı (TR), Assoc. Prof. Dr. Oral Yağcı (US), Prof. Dr. Seyfettin Taş (TR), Assoc. Prof. Dr. Ömer Suat Taşkın (TR), Dr. İnese Varna (LV), Dr. Petra Visser (NL), Prof. Dr. Selma Ünlü (TR), Assoc. Prof. Dr. İ. Noyan Yılmaz (AU), Prof. Dr. Murat Yakar (TR), Assit. Prof. Dr. Sibel Zeki (TR)

Abstracting and Indexing: DOAJ, Index Copernicus, OAJI, Scientific Indexing Services, Journal Factor, Google Scholar, Ulrich's Periodicals Directory, WorldCat, DRJI, ResearchBib, SOBIAD 


\title{
Modelling of the Oil Spill in M/V LADY TUNA Accident and the Evaluation of the Response Operation in Simulated Condition with PISCES II
}

\author{
Deniz Aydın, ${ }^{1 * *}$,Murat Selçuk Solmaz ${ }^{2}$ iD \\ ${ }^{1}$ Piri Reis University, Graduate School of Science and Engineering, Maritime Transportation and Management Engineering, İstanbul, TR \\ ${ }^{2}$ Piri Reis University, Maritime Faculty, Maritime Transportation and Management Engineering Department, İstanbul, TR
}

* Corresponding author: D. Aydın

Received 18 June 2019

* E-mail: denizkaldirimci21@gmail.com

Accepted 05 July 2019

How to cite: Aydın, D. \& Solmaz, M. S. (2019). Modelling of the Oil Spill in M/V Lady Tuna Accident and the Evaluation of the Response Operation in Simulated Condition with PISCES II. International Journal of Environment and Geoinformatics (IJEGEO), Vol. 6(2): 213-224, DOI: $10.30897 /$ jegeo.579066

\begin{abstract}
Oil pollution from ships is an important source of marine pollution and becomes an important problem all over the world. For this reason, every effort should be made to prevent oil spills and to remove them effectively as soon as pollution has emerged. In this respect, various computer simulations are used to get well informed about the fate of spilled oil on the seawater. In this study, the grounding accident of ship M/V Lady Tuna causing 75 tons of fuel spills into the sea on December 18, 2016, close to the coast of Çesme in Turkey, was investigated. The aim of the study is to investigate the oil spill accident and evaluate the response operation of M/V Lady Tuna. To achieve this aim, firstly the reports related to the accident were examined and the response operation was evaluated by modelling of the M/V Lady Tuna accident with PISCES II (Potential Incident Simulation, Control and Evaluation System) simulator. Within this scope, two scenarios were prepared by using PISCES II. The first scenario was created without any response resources to observe the movement direction of the oil slick after the accident. The second scenario was reconstructed with the possible response resources after the oil spill. Through simulation, it was possible to obtain the oil spill/pollution statistics; such as the recovered oil rate, the amount of stranded oil to the coast, the amount of floating oil rate, and other oil spill parameters. As a result, it was evaluated that the oil pollution in the M/V Lady Tuna accident could be responded more effectively and the pollution could be much less. It is assessed that the study will contribute to organizations involved in oil spill response operations.
\end{abstract}

Keywords: Oil Spill, Oil Spill Response Operation, M/V Lady Tuna, PISCES II.

\section{Introduction}

Oil pollution in the marine environment is one of the most important threats all over the world due to major oil spill disasters. When an oil spill occurs in the marine environment, all efforts must be made by governments and other organizations to prevent oil pollution. The best way to control the oil spill will take place if the response operations and emergency response strategies are already planned to prevent oil spillage as soon as possible. More recently, the advanced mathematical models have been created which are integrated with computer simulation to better predict oil's behavior and to take the best decisions for response operations by minimizing the environmental effect. For example; the OILMAP (Oil Spill Model and Response System, GNOME (General NOAA (National Oceanic and Atmospheric Administration) Operational Modelling Environment) and ADIOS (Automated Data Inquiry for Oil Spills) are computer programs which provide rapid predictions of the movement of spilled oil by entering both environmental and hydrodynamic data and specifying a spill scenario in the marine environment.

However, previous modeling studies of oil spills were based on experimental observations and the use of simple formulations to predict the spread of oil to seawater. The notable pioneer studies explaining fate of the spilled oil and physical process in the spread of oil on a water surface were improved by Fay (1969 and 1971), Mackay et al. (1980), Lehr et al. (1984), Delvigne at al. (1988), Güven et al., (2006), Doğan et al. (1998) and Fingas et al. (1996). Nowadays, it is widely used to make approaches that utilize advanced technology detection systems and various models in relation to oil accidents (Şeker, et al., 2013; Papila, et al., 2018; Abdikan, et al., 2018; Gazioğlu, et al., 2016, 2017; Gazioğlu, 2018). These studies take account of empirical measurements of spreading rates and analytical and theoretical studies of the physical processes.

PISCES II (Potential Incident Simulation, Control and Evaluation System II) is one of the computer software programs based on the mathematical modelling of an oil spill in marine environment. The simulation program predicts the oil spill behavior in water depending on spill parameters, the type of oil source, and environmental condition after the spillage. In addition, unlike many other programs, it is possible to manage the response operations in real time on the sea following the spillage. (PISCES II Manual, 2008)

Many processes control the behavior and condition of oil in marine environment. The properties of spilt oil change on the seawater over time, so it is important to know 
physical, chemical and weathering process of the oil when prediction behavior of the oil (ITOPF, 2002).

The movement of oil in the marine environment usually takes place in two directions. The movement in the horizontal direction occurs as a spread and causes the sea surface to be covered with oil or stranded to shoreline. The movement in the vertical direction occurs when the oil disperse or dissolute in the seawater. As a result of the movement, the oil sinks towards the bottom and becomes part of the sediment on the seabed.

The weathering process (spreading, evaporation, dispersion, emulsification, oxidation, biodegradation, dissolution and sedimentation) occurs when oil is exposed to environmental conditions such as in sea system (Fig. 1) (ITOPF, 2002).

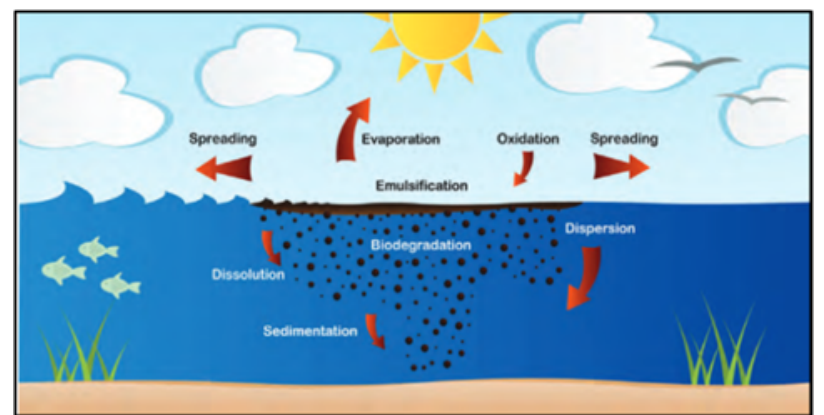

Figure 1. Weathering Processes Affecting Oil at Sea (ITOPF, 2002).

As shown in Fig. 2, the ratio of the weathering processes takes place at different rates and at different times. For example, spreading, evaporation, dispersion process takes place immediately in hours or days, but biodegradation, emulsification process takes place slowly over months or years.

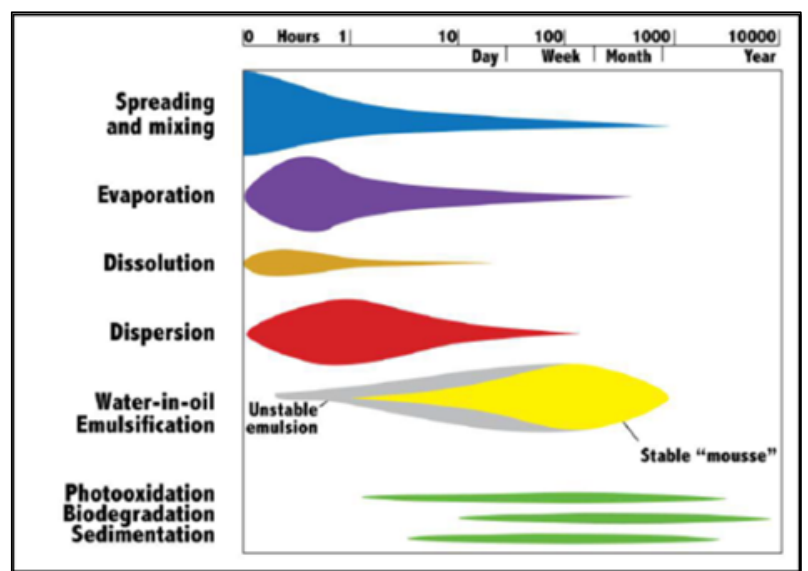

Figure 2. Weathering Processes (Boufadel et al., 2015).

The exception of petroleum products which have a higher density than sea water, they usually float on the surface when the oil enters in the marine environment and begin to spread. The viscosity of the oil and the amount of spilled oil affect the spreading speed of the oil on the sea. (ITOPF, 2002)
The effects of winds and currents significantly affect the spread of oil and resulting movement that can be calculated with sum of two vectors shown in Fig. 3 (Hault, 1972; Fingas, 2013). The wind-sourced current speed is assumed as 3\% (1\%-6\%) of wind velocity (Soltanpour et al., 2013).

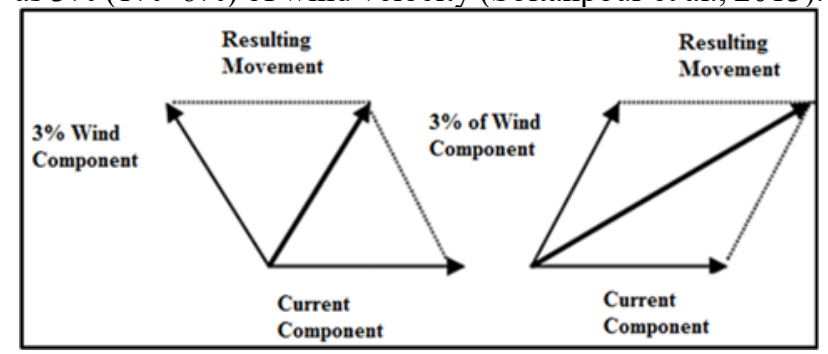

Figure 3. Oil Movement (Fingas, 2013).

\section{Materials and Methods}

In this study, firstly the reports related to the accident were investigated and then the response operation was evaluated by modelling of the M/V Lady Tuna accident with PISCES II simulator. In this concept, two scenario models were conducted for the study in simulated condition. The objectives of the scenarios are to illustrate possible response operations on the sea surface before the oil reaches the coast. The process steps applied in the study are shown in Fig. 4.

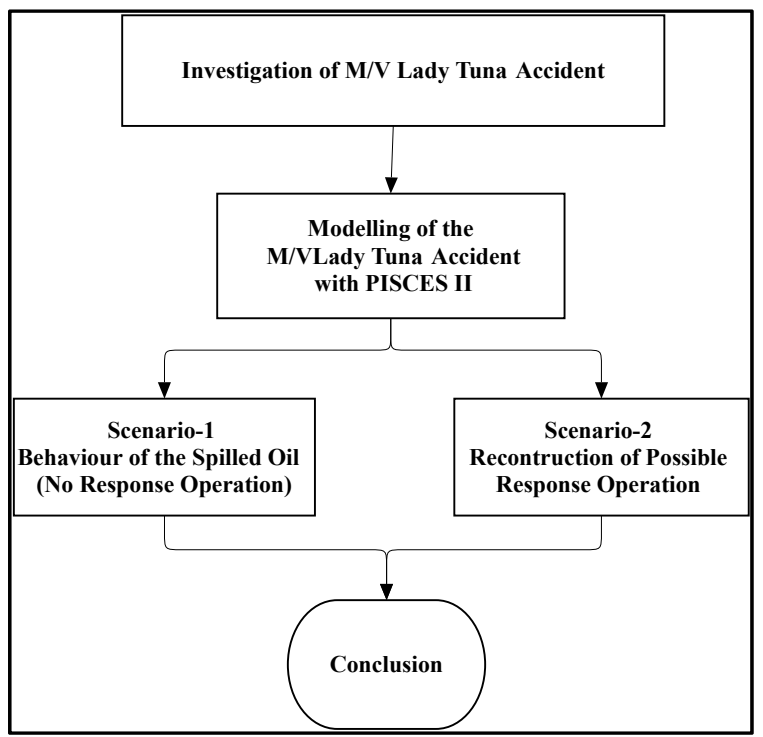

Figure 4. Flow chart of the Study

The information related to the incident data was obtained from the Investigation Report of M/V Lady Tuna marine accident. The reports are given as below:

- Marine Accident Investigation Report on the grounding of M/V Lady Tuna prepared by Accident Investigation Board (AIB) (32/DNZ-04/2017), the Ministry of Transport, Maritime Affairs and Communications, 2017.

- The Expert Report of M/V Lady Tuna was submitted to the Republic of Turkey Çeşme Civil Court of the First Instance by Sunlu, Kayacan and Küçükgül, 2017.

The environmental data was obtained from archive document of Meteorological Data Information Sales and 
Presentation System, Turkish State Meteorological Service (MEVBIS, 2017). The environmental data (air and water temperatures, wind direction and speed, sea state, the density of water and surface current) were manually put into the model.

\section{Investigation of the "M/V Lady Tuna" Accident}

M/V Lady Tuna, a Panamanian flagged vessel that came to make fish harvest from the tuna farms in the Ildır Bay which is under the administrative responsibility of Çeşme Port Authority, completed loading her cargo on 18.12.2016 and while she was proceeding to the anchorage area for custom clearance formalities at 13:30 LT. When the vessel was under way, master saw three small fishing vessels on starboard bow side of the vessel and altered the course to port side so as to avoid the collision. But, master could not realize the shallow waters on their port side and the vessel grounded at 13:36 LT on the shoal west of Ufak Island position while she was still under way at a speed of 11.7 knots. Master ordered to stop the engines at 13:42 LT. Soon after, the chief officer of the ship reported a fuel oil leak from the ship to the master at 13: $55 \mathrm{LT}$. The information about the vessel, navigation and accident are presented in Table 1. (AIB, 2017)

Table 1. Information about the Vessel, Navigation and Accident (AIB, 2017).

\begin{tabular}{|l|l|}
\hline Ship Name & M/V LADY TUNA \\
\hline Flag & Panama \\
\hline Class Society & NKK \\
\hline IMO Number & 9453438 \\
\hline Type of Ship & Fish Processing Vessel \\
\hline Gross Tonnage & 4538 GT \\
\hline LOA & 120,75 m \\
\hline Last Port of Call & Ildır Bay /Turkey \\
\hline Destination Port & Port Said / Egypt \\
\hline Cargo on Board & $\begin{array}{l}1223 \text { MT Processed Tuna } \\
\text { Fish }\end{array}$ \\
\hline Number of Crew & 33 persons \\
\hline Type of Sea Passage & High Seas \\
\hline $\begin{array}{l}\text { Date/Time of } \\
\text { Accident }\end{array}$ & $\begin{array}{l}18.12 .2016 / 13: 40 \text { LT } \\
\text { (GMT +3) }\end{array}$ \\
\hline Type of Accident & $\begin{array}{l}\text { Very Serious Marine } \\
\text { Casualty }\end{array}$ \\
\hline Location of Accident & Ildır Bay /Çeşme -İzmir \\
\hline Injured/Fatality/Loss & None \\
\hline Oil Pollution & $\begin{array}{l}\text { Fuel oil (IFO 180) } \\
\text { approximately 75 cubic } \\
\text { meters. }\end{array}$ \\
\hline
\end{tabular}

Gulf of Ildır is located between Karaburun Peninsula and Çeşme Canal in the west of Turkey. North coastal strip of Ildır Gulf is very narrow and shows a sudden deepening structure (Meriç et al., 2012). The accident happened near Fener Island in the Ildır Bay district of Çeşme province of İzmir (Lat: $38^{\circ} 23.26^{\prime} \mathrm{N}$ - Long: $026^{\circ} 25.42^{\prime} \mathrm{E}$ ) is shown in Fig. 5.

İstikbal and Erkan (2018), in their article, point out that this coast area surrounded by the fish farms are usually a kind of high-risk marine environment because of shallow waters and islands that are difficult to the navigation of the large tonnage vessels.

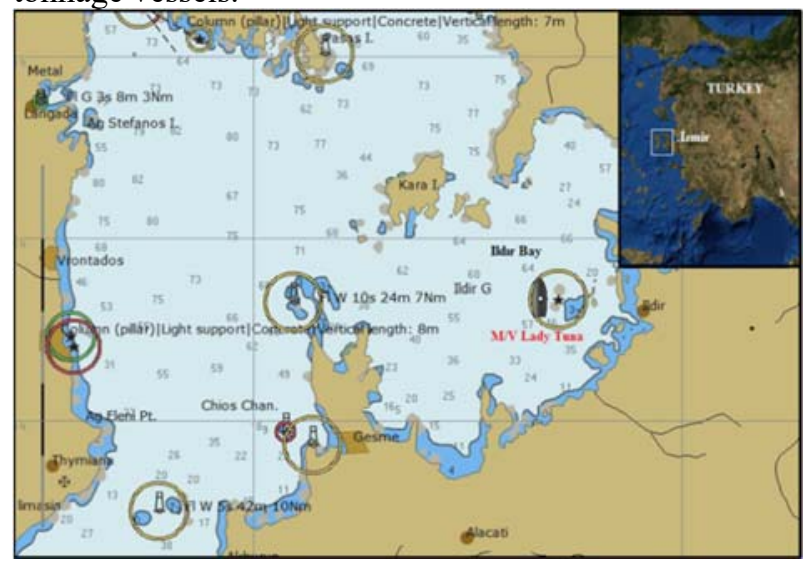

Figure 5. Position of the Accident (CPN, 2018).

As a result of the oil spills event, Ministry of Transport, Maritime Affairs and Communications, General Directorate of Marine and Inland Water Regulatory Affairs, has canceled the authority certificate of 9 of the 12 companies which were authorized by the Ministry. (Numbered: 36712415-160.03.02-E. 12358 dated 09.02.2017) (Notification to the Emergency Response Firms, 2017). Most Maritime and Environmental Services and Mare Marine Cleaning Services, managed the pollution response operation of the $\mathrm{M} / \mathrm{V}$ Lady Tuna, were among the companies whose license has been canceled by the Ministry.

\section{Events at the Aftermath of the Accident}

After the accident, the master of the ship informed to the agency about the oil pollution and reported that response operation was necessary urgently. There was no attempt by the ship to prevent oil pollution. After the soundings were taken from the tanks by the crew, it was determined that there were damages to fore-peak tank, No.1 center ballast tank, No.1 center fuel tank, No.2 port and starboard fuel tanks. There was leakage from the fuel tanks to the sea. Damaged parts of the ship on the Transverse Plan are shown in Fig. 6. (AIB, 2017)

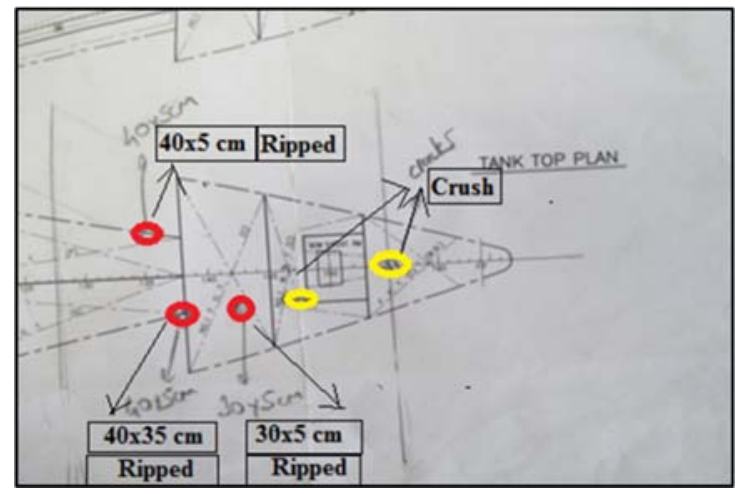

Figure 6. Damaged Parts of the Ship (AIB, 2017).

At 15.00 LT (1,5 $\mathrm{h}$ after the accident), ship's agent called the pollution response company Most Maritime and Environmental Services which was based at Ulusoy Port, in the administrative responsibility area of Çeşme Port Authority, to make the necessary preparations. Çeşme Port Authority ordered the ship's agent to start necessary 
pollution response activities at 17:30 LT (4 h after the accident). Most Shipping started to encircle the fish farms with barriers at 20:30 LT and they completed to encircle the ship to the containment of pollution with barriers with two skimmers at 22:30 LT (Fig. 7) (9 h after the fuel oil leakage from the ship). As of 12:00 LT on 19th December 2016 (about a day after the accident), another company "Mare Marine Cleaning Service Company" started to work for pollution response. (AIB, 2017)

However, according to the captain's statement, the time of the accident was recorded in the ship's logbook at 13:30 LT. The insufficient boom was encircled to the ship at 00:30 LT on 19 December 2016 (11 h later) to control the pollution arising from the ship. Because of the bad weather condition, the second barrier was encircled $20 \mathrm{~h}$ after the spillage. (Sunlu, Kayacan and Küçükgül, 2017)

It shows that there are differences and inconsistencies in the documents of the official institutions about how fuel oil pollution started in the events and how they manage the response operation following the spillage from the ship.

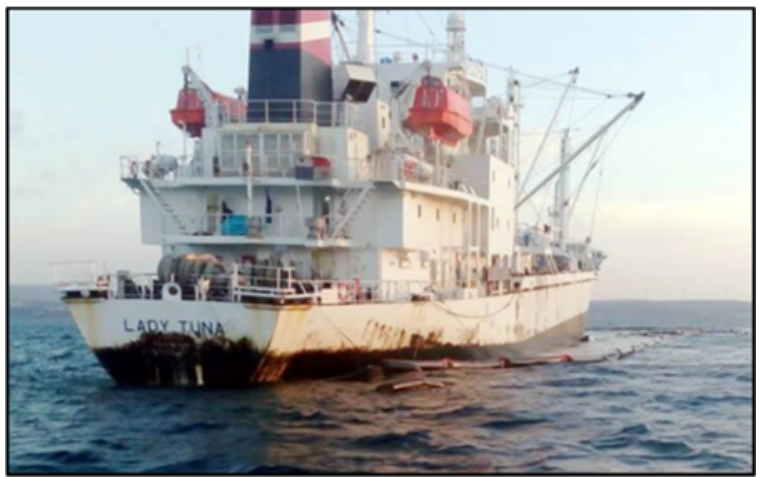

Figure 7. Containment of Spilled Oil by Barriers (www.seanews.com.tr, 2017).

Distance from the Ulusoy Çeşme Port to the accident position is about 12 nautical miles (NMs) by the sea and about $20 \mathrm{~km}$ by the land road (Fig. 8). The accident position is very close to the other international ports (Port of İzmir, Alsancak and Nemrut) by the seaway and land road. It means the response equipments could be delivered to the accident area quickly.

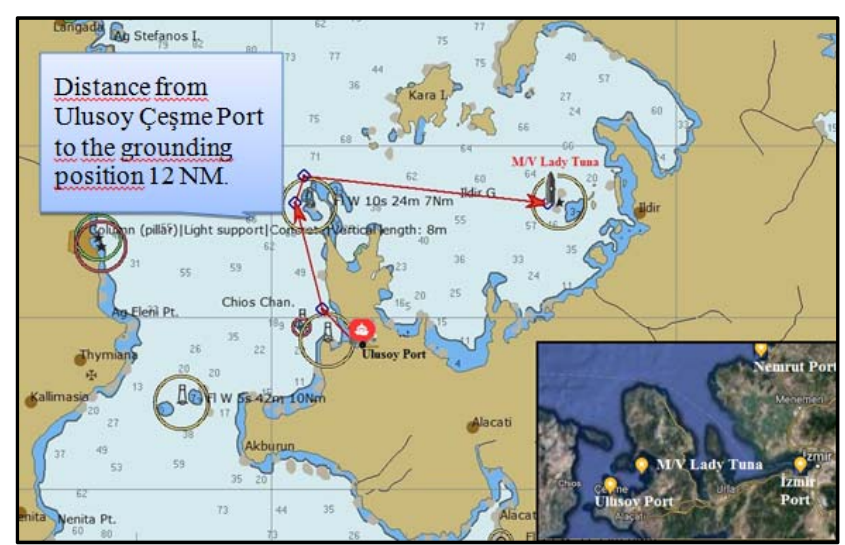

Figure 8. Distance from Ulusoy Çeşme Port to the Grounding Position (CPN, 2018).
On 24th December 2016 (6 days after the accident), tanker ship Petrol-1 (Fig. 9) came alongside M/V Lady Tuna in order to discharge the fuel in her damaged parts. The discharging operation was completed on 26th December 2016 ( 8 days after the accident). Salvage operations were started at 09:00 LT on 27th December 2016, 9 days after the accident. (AIB, 2017)

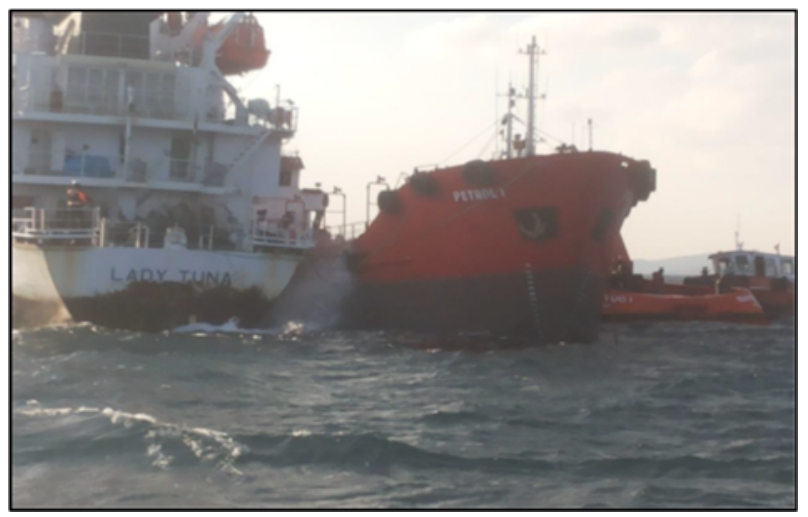

Figure 9. Transfer Operation (AIB, 2017).

The weather report of the Ilıca/Çeşme Weather Station is presented in Fig. 10. It shows that the violent storm occurs after the accident when the fuel oil continued to spill into the sea from M/V Lady Tuna. It has been thought that the physical insufficiency of the barrier placed around the ship and the extreme weather conditions increased the volume of the spilled oil.

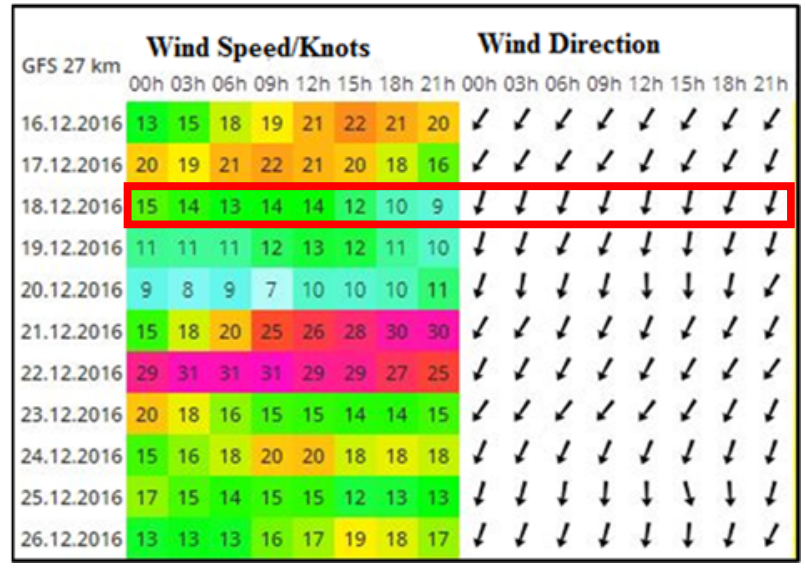

Figure 10. Wind Speed and Direction (www.windguru.cz, 2018).

\section{Modelling of the Oil Spills in M/V Lady Tuna Accident with PISCES II}

PISCES II program is used to control and predict the propagation of oil spills based on the mathematical modelling. The simulation program also provides planning of the response operation in real time to prevent oil pollution on the seawater.

Fig. 11 shows the general appearance of chart view of the control panel and the scenario checklist window in PISCES II. The "Scenario Checklist" window displays a list of parameters to be specified and actions to be performed to prepare the scenario. 
The tasks in the list are divided for convenience into several categories:

- Specification of the impact area,

- Specification of environmental conditions,

- Pollution parameters,

- Response resources.

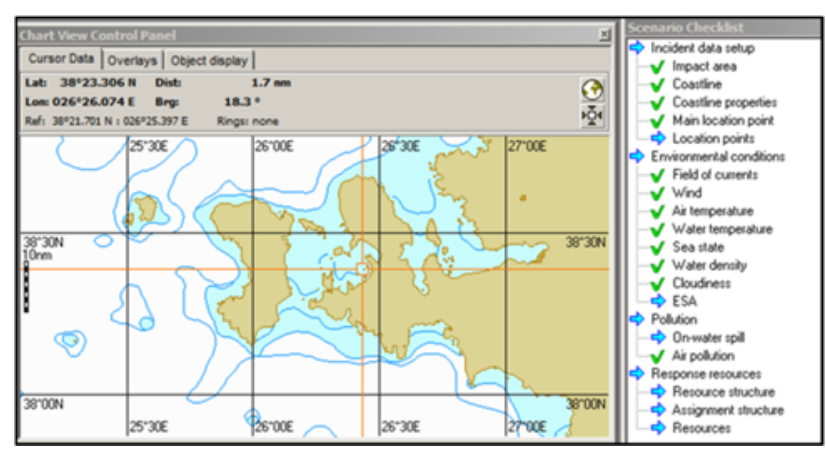

Figure 11. The Scenario Checklist Layout.

\section{Scenario-1: Behaviour of the Spilled Oil on Seawater (No Response Operation)}

The Scenario-1 was started at 10:40 UTC on 18 December 2016 and ended 22:40 UTC on 19 December 2016 (36 h) in simulated condition with PISCES II (UTC +3 to convert local time in the 2016 year). The information about scenario duration was presented in Table 2 .

Table 2. The Duration of Scenario-1 with PISCES II.

\begin{tabular}{|c|c|c|c|}
\hline $\begin{array}{c}\text { Scena } \\
\text { rio }\end{array}$ & $\begin{array}{c}\text { Time } \\
\text { (UTC) }\end{array}$ & Date & $\begin{array}{c}\text { Time from } \\
\text { Scenario Start }\end{array}$ \\
\hline Begin & $10: 40$ & $\begin{array}{c}18.12 .2 \\
016\end{array}$ & $36 \mathrm{~h}$ \\
\hline End & $22: 40$ & $\begin{array}{c}19.12 .2 \\
016\end{array}$ & \\
\hline
\end{tabular}

The characteristics of fuel oil "IFO 180" used in the experiment are presented in Table 3.

Table 3. Characteristics of the IFO 180, (PISCES II Manual, 2008).

\begin{tabular}{|c|c|}
\hline Name of the product & IFO 180 \\
\hline Type & Refined \\
\hline Group & IV \\
\hline Density & $968 \mathrm{~kg} / \mathrm{m}^{3}$ \\
\hline Viscosity & $2324 \mathrm{cP}($ centipoise $)$ \\
\hline Maximum content of water & $25 \%$ \\
\hline Emulsification constant & $0 \%$ \\
\hline Pour point & $-10^{\circ} \mathrm{C}$ \\
\hline Flash Point & $91{ }^{\circ} \mathrm{C}$ \\
\hline
\end{tabular}

The effects of wind and currents significantly affect the drifting of the oil at the sea surface. The direction and speed of the surface current for the moment of the accident in Ildır Bay have not been measured by Turkish State Meteorological Service.

The general pattern of current varies depending on meteorological conditions and wind direction in considerable duration affect the surface current on the sea.
To know more about the dominant wind direction of Ildir Bay, wind statistics for Çeşme were displayed in Fig. 12. So, the general direction of the surface currents was adopted towards $\mathrm{SW}\left(225^{\circ}\right)$ under the effect of the regional wind from NE and NNE direction.

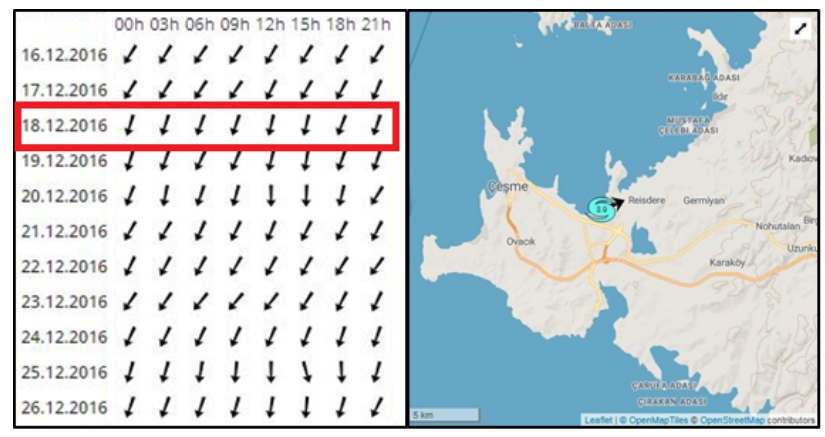

Figure 12. Wind Direction of Ilıca/Çeşme and Station Position (www.windguru.cz, 2018).

In the real case, the flow rate of the oil spillage (per hour) from the ship could not be determined. Considering the damaged parts of the ship, the amount of the oil spill rate was assumed as 5 tons/per hour.

The environmental data were manually placed in the model and then the software simulation started with the combining of other related components. Thus, the simulation was performed on the following data:

\section{i. Incident Data Set-up:}

- Date of accident; 18th of December 2016, 13:40 Local Times (GMT +3),

- Accident position; Lat: $38^{\circ} 23,26^{\prime} \mathrm{N} /$ Long: $026^{\circ}$ $25,42^{\prime} \mathrm{E}$,

- Impact area was defined,

- Coastline properties,

- Main location points and location points were set near the accident point.

\section{ii. Environmental Conditions:}

- Field of current: Direction $225^{\circ}$ (towards SW), speed $0,16 \mathrm{kts}$,

- Field of wind: Direction from NE,

- Air temperature: $9{ }^{\circ} \mathrm{C}$,

- Water temperature: $13,9^{\circ} \mathrm{C}$,

- Sea state: 3 feet,

- Seawater density: $1029 \mathrm{~kg} / \mathrm{m} 3$,

- Cloudiness: 0 .

\section{iii. Pollution-on Water Spill:}

- Type of oil: IFO 180 ,

- Amount spilled: 72.5 tons $(75 \mathrm{~m} 3)$,

- Rate: 5 tons/ per hour.

In the first scenario, no response resources were used during the simulation. When the oil spilled, it immediately began to spread on the surface of the sea. The fate of spilled oil water movement rapidly breaks up oil films, which drift on the water surface. The movement of the oil slick after 
the accident was towards SW direction which drifts in response to the wind and the current (Fig. 13). The pollution and spillage parameters after $6 \mathrm{~h}$ from the accident are presented in Table 4.

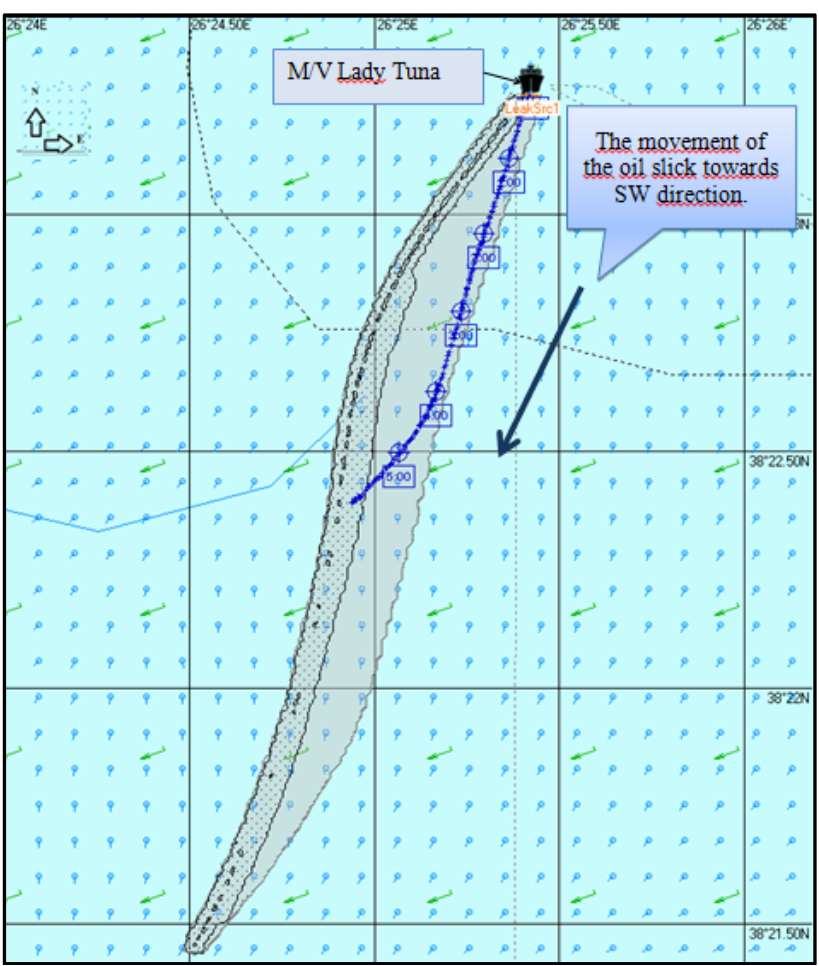

Figure 13. Movement Direction of the Oil Slick ( $\Delta \mathrm{t}: 6 \mathrm{~h})$.

Table 4. Oil Spill Parameters of Scenario-1 after $6 \mathrm{~h}$.

\begin{tabular}{|l|r|r|}
\hline \multicolumn{1}{|c|}{ Oil } & \multicolumn{1}{|c|}{ Parameter } & \multicolumn{1}{c|}{$\begin{array}{c}\text { Percentage } \\
(\%)\end{array}$} \\
\hline Amount spilled & 30,0 tons & 100 \\
\hline Amount floating & 29,8 tons & 99,4 \\
\hline $\begin{array}{l}\text { Amount } \\
\text { evaporated }\end{array}$ & 0,2 tons & 0,52 \\
\hline Amount dispersed & 0,0 tons & \\
\hline Amount stranded & 0,0 tons & \\
\hline $\begin{array}{l}\text { Amount floating } \\
\text { mixture }\end{array}$ & 35,6 tons & \\
\hline $\begin{array}{l}\text { Max thickness of } \\
\text { slick oil }\end{array}$ & $1,4 \mathrm{~mm}$ & \\
\hline Slick area & $0384882 \mathrm{~m}^{2}$ & \\
\hline $\begin{array}{l}\text { Viscosity of slick } \\
\text { oil }\end{array}$ & $2149 \mathrm{cP}$ & \\
\hline
\end{tabular}

The rate of dispersion is largely dependent upon the nature of the oil (the viscosity) and the sea state. The dispersion started at a very low rate about $11 \mathrm{~h}$ from the spillage because of the high viscosity rate of the fuel oil in the model and the gentle-moderate weather condition.

The area shown in gray color indicates the area where oil is spreading for up to $12 \mathrm{~h}$ from the beginning of the scenario (spilled oil; 60 tons) (Fig. 14). The program shows the information "Oil impact on land" on the window screen. The oil reached on the Paşalimanı coast $(0,02 \%)$ about $12 \mathrm{~h}$ later following the spillage (Table 5).

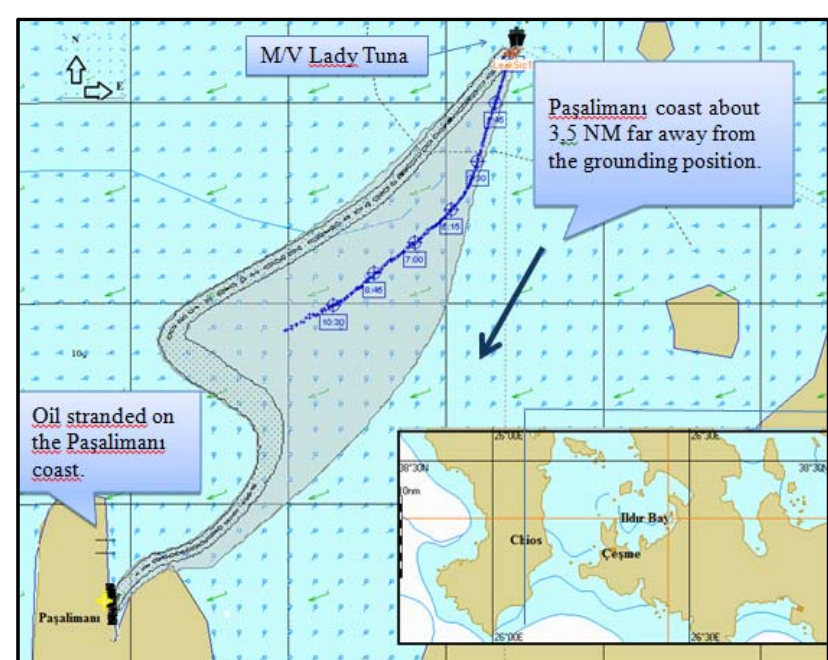

Figure 14. Scenario-1: The Oil Stranded on the Paşalimanı Coast $(\Delta \mathrm{t}: 12 \mathrm{~h})$.

Table 5. Oil Spill Parameters of Scenario-1 after $12 \mathrm{~h}$.

\begin{tabular}{|l|r|r|}
\hline \multicolumn{1}{|c|}{ Oil } & Parameter & \multicolumn{1}{c|}{$\begin{array}{c}\text { Percentage } \\
(\mathbf{\% )}\end{array}$} \\
\hline Amount spilled & 60,0 tons & 100 \\
\hline Amount floating & 59,0 tons & 98,5 \\
\hline $\begin{array}{l}\text { Amount } \\
\text { evaporated }\end{array}$ & 0,8 tons & 1,41 \\
\hline Amount dispersed & 0,1 tons & 0,09 \\
\hline Amount stranded & 0,02 tons & 0,02 \\
\hline $\begin{array}{l}\text { Amount floating } \\
\text { mixture }\end{array}$ & 73,9 tons & \\
\hline $\begin{array}{l}\text { Max thickness of } \\
\text { slick oil }\end{array}$ & $0,8 \mathrm{~mm}$ & \\
\hline Slick area & $129276 \mathrm{~m}^{2}$ & \\
\hline $\begin{array}{l}\text { Viscosity of slick } \\
\text { oil }\end{array}$ & $2685 \mathrm{cP}$ & \\
\hline
\end{tabular}

As a result of the scenario, the movement direction of the oil slick after $36 \mathrm{~h}$ from the accident is shown in Fig. 15. It is clearly seen that the oil was stranded at Paşalimanı coast, the Boyalık Bay, the Setur Çeşme Marina, the Radisson Blue Resort Hotel beach, the Ilica Hotel beach, the Yildizburnu coast, Sherotan Hotel beach and the Ilica public beaches. The pollution and spill parameters (after $36 \mathrm{~h}$ ) are presented in Table 6.

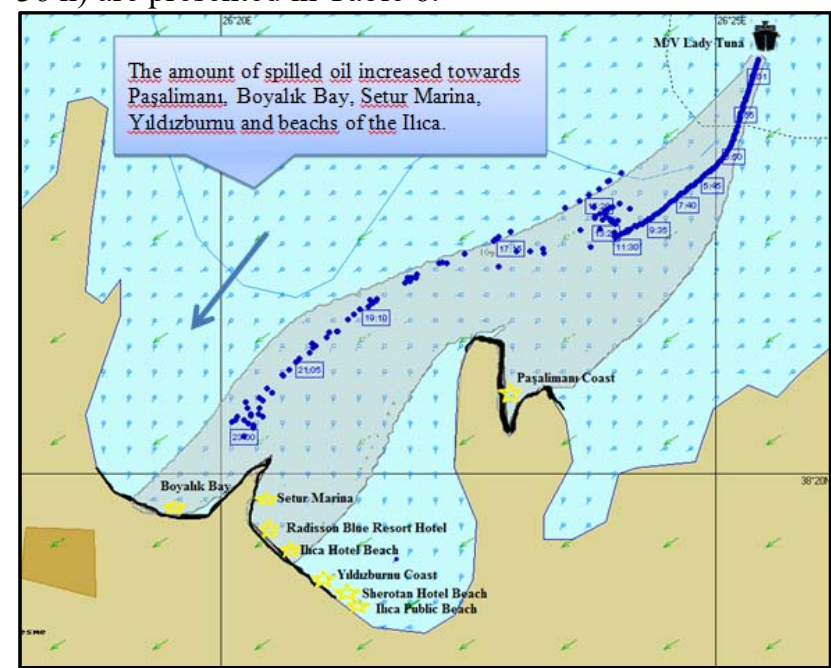

Figure 15. Scenario-1: The Movement direction of the oil slick $(\Delta \mathrm{t}: 36 \mathrm{~h})$. 
Table 6. Oil Spill Parameters of Scenario-1 after $36 \mathrm{~h}$.

\begin{tabular}{|l|r|r|}
\hline Oil & Parameter & \multicolumn{1}{|c|}{$\begin{array}{c}\text { Percentage } \\
(\mathbf{\%})\end{array}$} \\
\hline Amount spilled & 72,5 tons & 100 \\
\hline Amount floating & 18,4 tons & 25,4 \\
\hline $\begin{array}{l}\text { Amount } \\
\text { evaporated }\end{array}$ & 2,3 tons & 3,18 \\
\hline Amount dispersed & 0,4 tons & 0,51 \\
\hline Amount stranded & 51,4 tons & 70,9 \\
\hline $\begin{array}{l}\text { Amount floating } \\
\text { mixture }\end{array}$ & 24,9 tons & \\
\hline $\begin{array}{l}\text { Max thickness of } \\
\text { slick oil }\end{array}$ & $17,4 \mathrm{~mm}$ & \\
\hline Slick area & $5705 \mathrm{~m}^{2}$ & \\
\hline $\begin{array}{l}\text { Viscosity of slick } \\
\text { oil }\end{array}$ & $4010 \mathrm{cP}$ & \\
\hline
\end{tabular}

As a result of the study, it was available to determine and compare the spill and pollution statistics occurred after the incident in the simulated condition as graphically (Fig.16). So, the following results are obtained in the Scenario-1;

- After $14 \mathrm{~h}$ and 30 minutes following the accident, 72,5 tons fuel oil leaked from the ship's tanks (5 tons/per hour). - The amount of stranded oil (which began about $12 \mathrm{~h}$ after the spillage), is 51,4 tons ( $70,9 \%$ of the spilled oil) as well as the floating oil amount is 18,4 tons $(25,4 \%$ of the spilled oil).

- The remaining amount of the spilled oil were dispersed $(0,51 \%)$ and evaporated $(3,18 \%)$. It means the evaporation and dispersion rate is very low due to the nature of the oil (IFO 180, the heavy fuel oil) as well as the moderate sea state.

- The amount of floating oil increased until $14 \mathrm{~h}$ following the accident. After this time the floating oil rate decreased because the oil reached on the coast as well as the fuel leakage ended after $14 \mathrm{~h}$ and $30 \mathrm{~min}$.

- The spilled oil on the surface of the sea spreads depending on the environmental conditions, the properties and amount of the spilled oil.

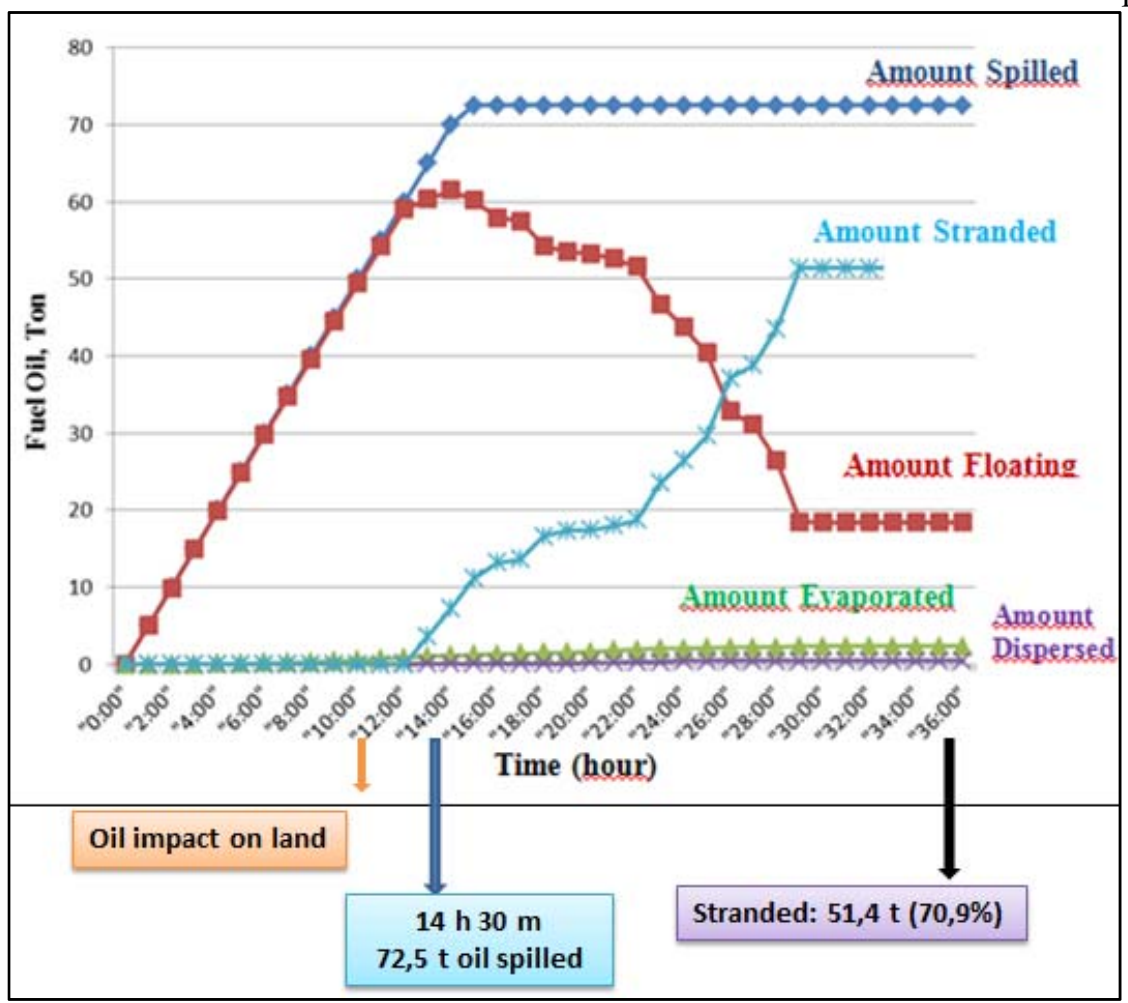

Figure 16. The Graphic of the Spill/ Pollution Statistics of the Scenario-1.

Table 7. Duration of the Scenario-2 with PISCES II.

\begin{tabular}{|l|c|c|c|}
\hline Scenario & Time & Date & $\begin{array}{c}\text { Time from Scenario } \\
\text { Start }\end{array}$ \\
\hline Begin & $10: 40$ & 18.12 .2016 & \multirow{2}{*}{$15 \mathrm{~h}$} \\
\hline End & $01: 40$ & 19.12 .2016 & \\
\hline
\end{tabular}

Table 8. Parameters of the Response Resource Equipments (PISCES II Manual,

\begin{tabular}{|c|c|c|c|c|c|}
\hline \multicolumn{2}{|c|}{ Model Data of the Skimmer Type } & \multicolumn{2}{|c|}{$\begin{array}{c}\text { Model Data of the Boom } \\
\text { Type }\end{array}$} & \multicolumn{2}{|c|}{ Features of the Boat } \\
\hline Type & Oleophilic Skimmer & Type & Open Water Boom & Type & $\begin{array}{l}\text { Oilfield Supply } \\
\text { Vessel }\end{array}$ \\
\hline Storage Capacity & $11 \mathrm{~m}^{3}$ & Height & $1.97 \mathrm{ft}$. & Max Speed & 14 kts. \\
\hline Recovery Rate & 3,54 tons/hour & Depth & $3.61 \mathrm{ft}$. & Draft & $1 \mathrm{~m}$ \\
\hline Sea factor & $0.0,1.0 ; 0.8,1.0 ; 1.3,0.5$ & Slack & $5 \%$ & LOA & $20 \mathrm{~m}$. \\
\hline Recovery Radius & $20 \mathrm{~m}$ & Absorb Capacity & $0 \mathrm{~m}^{2}$ & Range & $200 \mathrm{NMs}$ \\
\hline
\end{tabular}




\section{Scenario-2: Reconstruction of Possible Response Operation with PISCES II}

The Scenario-2 was reconstructed with the possible response resources after the oil spill. The simulator PISCES II provides an illustration of the possible response operation on seawater. The information about the Scenario-2 duration (Table 7) is presented as above.

During the oil recovery operation, the parameters of the response equipment were presented in Table 8 (above).

The oil skimmers remove the floating oil from the point they are located. Model selection of the skimmer determines the rated capacity of the skimmer and the dependence of oil skimming efficiency on the oil viscosity and the wave height. Table 9 shows the characteristics of the Oleophilic skimmer presented in PISCES II. The wave height of the sea at the time of the accident is adopted as 3 feet. The viscosity of the oil IFO 180 is $2324 \mathrm{cP}$ in the program.

Table 9. The Characteristics of the Oleophilic Skimmer (PISCES II Manual, 2008).

\begin{tabular}{|c|c|c|c|c|}
\hline \multirow{4}{*}{$\begin{array}{c}\text { Skimmer } \\
\text { Model }\end{array}$} & \multicolumn{2}{|c|}{$\begin{array}{c}\text { Dependence of oil } \\
\text { skimming } \\
\text { efficiency on the } \\
\text { wave height }\end{array}$} & \multicolumn{2}{|c|}{$\begin{array}{c}\text { Dependence of oil } \\
\text { skimming } \\
\text { efficiency on the oil } \\
\text { viscosity }\end{array}$} \\
\cline { 2 - 5 } & $\begin{array}{c}\text { Wave } \\
\text { height } \\
\text { (feet) }\end{array}$ & $\begin{array}{c}\text { Efficiency } \\
(\%)\end{array}$ & $\begin{array}{c}\text { Viscosity } \\
(\mathrm{cP})\end{array}$ & $\begin{array}{c}\text { Efficiency } \\
(\%)\end{array}$ \\
\hline \multirow{5}{*}{ Oleophilic } & 0 & 100 & 0 & 10 \\
\cline { 2 - 5 } & 2.62 & 100 & 500 & 40 \\
\cline { 2 - 5 } & 4.27 & 50 & 1500 & 90 \\
\cline { 2 - 5 } & 5.91 & 0 & 2500 & 60 \\
\cline { 2 - 5 } & & & 5000 & 10 \\
\cline { 2 - 5 } & & & 10000 & 0 \\
\hline
\end{tabular}

The incident data, the environmental conditions and the amount of spillage on seawater are the same as in the first scenario. The only difference was that the response resources created to containment and recovery of an oil spill during the simulation. These were an open water Boom-1 for the oil containment, an open water Boom-2 arranged $\mathrm{J}$ shape formation for the oil collection by trawling, three Oleophilic skimmers and three oilfield supply vessels. The event log of the recovery process is presented in Table 10.

Table 10. Event Log of the Recovery Process.

\begin{tabular}{|c|c|}
\hline $\begin{array}{c}\text { Time (UTC) } \\
18.12 .2016\end{array}$ & The Response Resources \\
\hline $10: 40$ & The fuel oil began to leak. \\
\hline $\begin{array}{c}3 \mathrm{~h} \text { after spillage } \\
13: 40\end{array}$ & $\begin{array}{l}\text { The Oil Containment Boom Formation-1 } \\
\text { Deployed; Oleophilic Skimmer-1 and } \\
\text { Skimmer-2; An Oilfield Supply Vessel. }\end{array}$ \\
\hline $\begin{array}{c}5 \mathrm{~h} \text { after spillage } \\
15: 40\end{array}$ & $\begin{array}{l}\text { J Shape Boom Formation-2 Deployed; } \\
\text { Oleophilic Skimmer-3; Two Oilfield } \\
\text { Supply Vessels. }\end{array}$ \\
\hline $\begin{array}{c}7 \mathrm{~h} \text { after spillage } \\
17: 40\end{array}$ & $\begin{array}{l}\text { Oleophilic Skimmer-1 and Skimmer-2 } \\
\text { exceed storage capacity }\left(11 \mathrm{~m}^{3}\right) \text {; } \\
\text { Oleophilic Skimmer-1 and Skimmer-2 } \\
\text { Rearranged. }\end{array}$ \\
\hline
\end{tabular}

The accident occurred at 10:40 UTC (13:40 LT) on 18 December 2016. The open water Boom-1 and the Oleophilic skimmers were placed on the sea at 13:40 UTC ( $3 \mathrm{~h}$ after spillage). The deployed oil containment Boom Formation-1 prevented spreading of the oil slicks. The Oleophilic Skimmers-1 and Skimmer-2 removed the floating oil from the point they located in the boom formation. An oilfield supply vessel assisted the operation. Before the response resources started to the task, about 15 tons oil had spilled to seawater in three hours.

The one $\mathrm{J}$ shape Boom Formation-2 was placed on the scene with the Oleophilic Skimmer-3 and two Oilfield supply vessels as a single unit at 15:40 UTC ( $5 \mathrm{~h}$ after the spillage). Movement of the J shape Boom Formation- 2 was controlled by two Oilfield supply vessels and it allowed the oil collecting by trawling (Fig. 17). J shape Boom Formation-2 (300 m open water boom) was adjusted in the direction of the oil leak and moved with an Oleophilic skimmer towards the leakage source. The Response Operation with Oil Containment Boom Formation-1 and $\mathbf{J}$ Shape Boom Formation-2 were presented in Fig. 18.

At 17.40 UTC (about $7 \mathrm{~h}$ after the spillage), the Oleophilic Skimmer-1 and Skimmer-2 (combined with the containment boom-1) removed the floating oil and exceed the storage capacity which is $11 \mathrm{~m} 3$. Therefore the Oleophilic Skimmer-1 and Skimmer-2 were rearranged as combined with the Boom Formation-1.

At the end of the $9 \mathrm{~h}$, the skimmers removed the floating oil from the point they located, about 31,5 tons oil on-water was recovered $(69,7 \%$ of the spilled oil) in simulated condition. Oil spill parameters after $9 \mathrm{~h}$ from spillage are presented in Table 11.

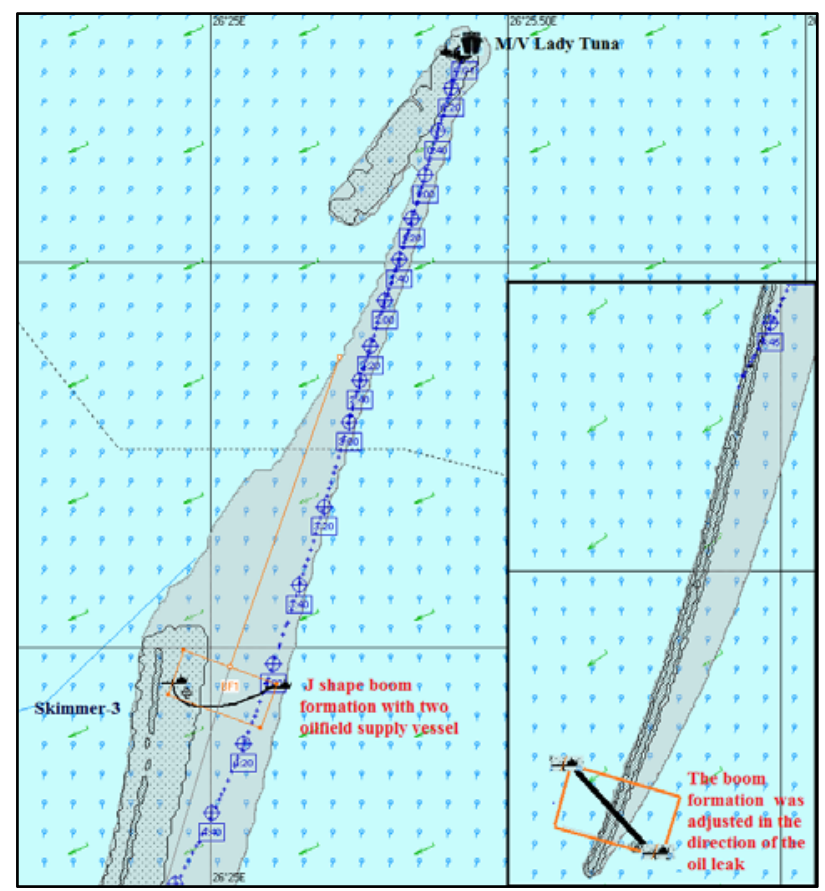

Figure 17. The Movement of the J Shape Boom Formation-2 with the Skimmer-3. 


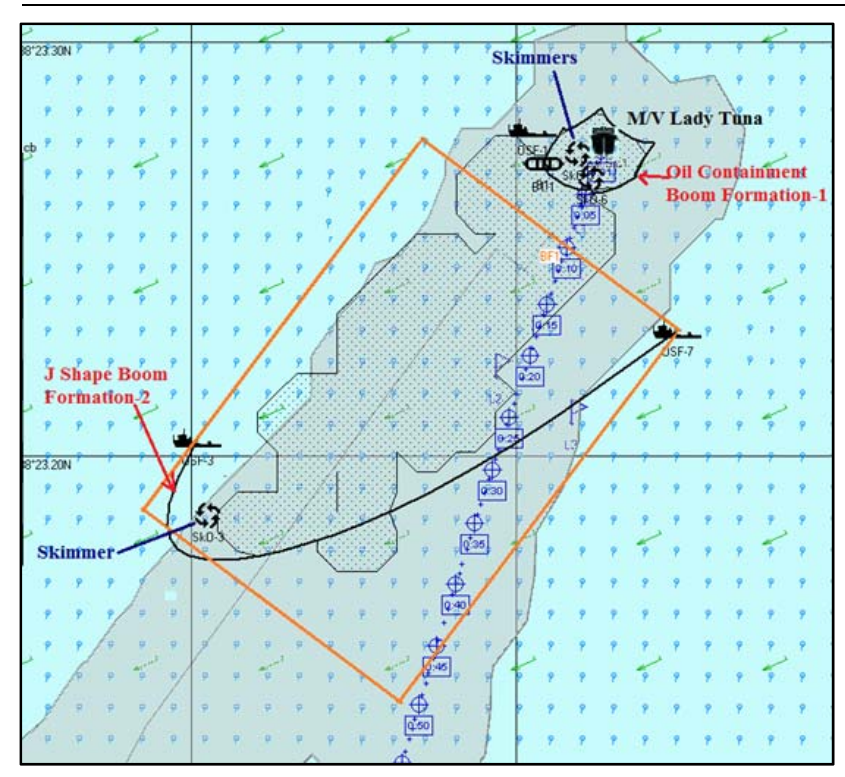

Figure 18. The Response Operation with Oil Containment Boom Formation-1 and J Shape Boom Formation-2.

Table 11. Oil Spill Parameters of Scenario-2 after $9 \mathrm{~h}$.

\begin{tabular}{|l|r|r|}
\hline \multicolumn{1}{|c|}{ Oil } & \multicolumn{1}{|c|}{ Parameter } & Percentage (\%) \\
\hline Amount spilled & 45,2 tons & 100 \\
\hline Amount floating & 13,5 tons & 29,8 \\
\hline Amount evaporated & 0,2 tons & 0,48 \\
\hline Amount dispersed & 0,01 tons & 0,03 \\
\hline Amount stranded & 0 tons & 0 \\
\hline Amount recovered & 31,5 tons & 69,7 \\
\hline $\begin{array}{l}\text { Amount floating } \\
\text { mixture }\end{array}$ & 17,8 tons & \\
\hline $\begin{array}{l}\text { Amount recovered } \\
\text { mixture }\end{array}$ & 31,9 tons & 1,17 \\
\hline $\begin{array}{l}\text { Max thickness of } \\
\text { slick oil }\end{array}$ & $0,8 \mathrm{~mm}$ & \\
\hline Slick area & $378042 \mathrm{~m}^{2}$ & \\
\hline Viscosity of slick oil & $2783 \mathrm{cP}$ & \\
\hline
\end{tabular}

The "Local Area Statistics" window shows statistics for the polygon area. The local statistics of the the area was presented in Fig. 19, which displayed maximum thickness and area of the patch, amount of oil product afloat and stranded oil. It displayed pollution statistics of the Paşalimanı coast where is the first impacted coast from the oil spill (about 3,5 NMs far away from the accident position).

The display of oil pollution in gray color indicates the size of the entire polluted area from the start of the scenario until $15 \mathrm{~h}$ following the spillage. After using the resources of response on the sea, it is observed that the direction of oil has changed.

In the second scenario, when the response resources were organized in simulated condition, 58.8 tons oil was recovered. So, the amount of the oil which reached the shore reduced after the response operation. The illustrated response operation allowed making a conclusion about the pollution/spill parameters of M/V Lady Tuna accident is displayed in Table 12.

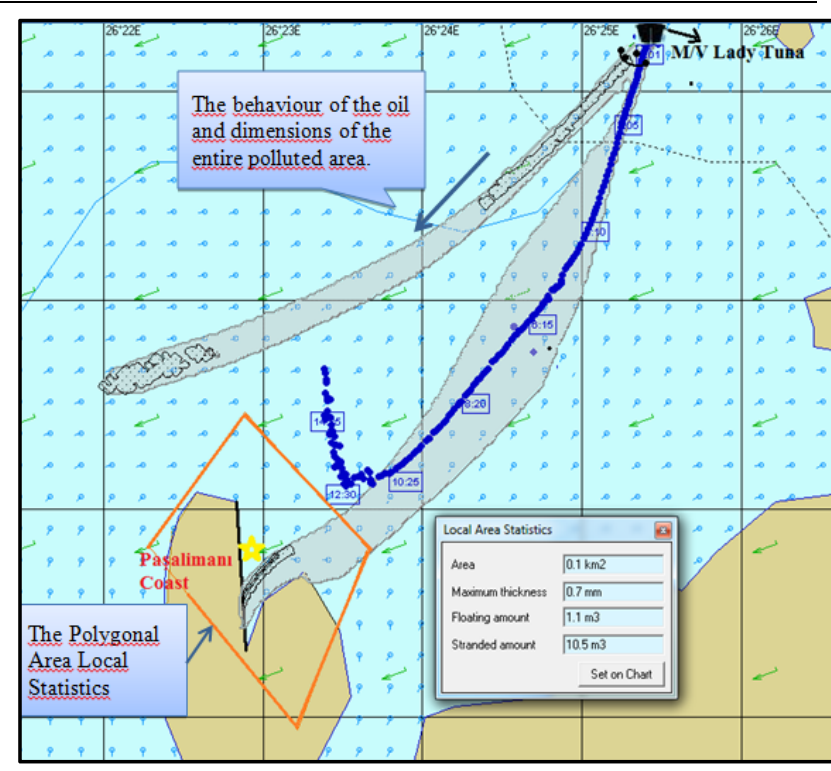

Figure 19. The Behavior of the Spilled Oil and Local Area Statistics $(\Delta \mathrm{t}: 15 \mathrm{~h})$.

Table 12. Oil Spill Parameters of Scenario-2 after $15 \mathrm{~h}$.

\begin{tabular}{|l|r|r|}
\hline \multicolumn{1}{|c|}{ Oil } & Parameter & Percentage (\%) \\
\hline Amount spilled & 72,5 tons & 100 \\
\hline Amount floating & 3,3 tons & 4,6 \\
\hline Amount evaporated & 0,4 tons & 0,55 \\
\hline Amount dispersed & 0,02 tons & 0,03 \\
\hline Amount stranded & 10,0 tons & 13,7 \\
\hline Amount recovered & 58,8 tons & 81,1 \\
\hline $\begin{array}{l}\text { Amount floating } \\
\text { mixture }\end{array}$ & 4,5 tons & \\
\hline $\begin{array}{l}\text { Amount recovered } \\
\text { mixture }\end{array}$ & 59,3 tons & 0,81 \\
\hline $\begin{array}{l}\text { Max thickness of } \\
\text { slick oil }\end{array}$ & $0,8 \mathrm{~mm}$ & \\
\hline Slick area & $388922 \mathrm{~m}^{2}$ & \\
\hline Viscosity of slick oil & $2918 \mathrm{cP}$ & \\
\hline
\end{tabular}

The main objective of the Scenario-2 is to illustrate actions to response oil pollution on the sea surface before it reaches the shoreline where it will create the most amount of destruction.

The simulation PISCES II showed a significant influence on the efficiency of oil spill recovery from the surface of the sea. Results of the spill/pollution statistics are graphically presented in Fig. 20. So, the following results are obtained in the Scenario-2;

- After 14 hours and 30 minutes following the accident, 72.5 tons fuel oil leaked from the ship's tanks. The oil stranded on the Paşalimanı coast (3,5 NMs far away from the accident) about $12 \mathrm{~h}$ after the spillage.

- Because the containment Boom-1 with two skimmers was deployed around the ship after $3 \mathrm{~h}$ following the spillage, the only 15 tons of oil spread to seawater in three hours.

- The J shape Boom Formation-2 with one Oleophilic skimmer was placed on the scene and recovered about 5 tons oil on the sea by trawling. But, 10 tons oil reached the coast. Because, the oil slick area was more than the booms' radius; the effectiveness of the 
skimmer reduced due to floating oil-water emulsification process and the Oleophilic skimmer has $20 \mathrm{~m}$ recovery radius which restricted removing of the floating oil.

- Thanks to the response operation, the amount of the oil which reached the shore reduced. The spill

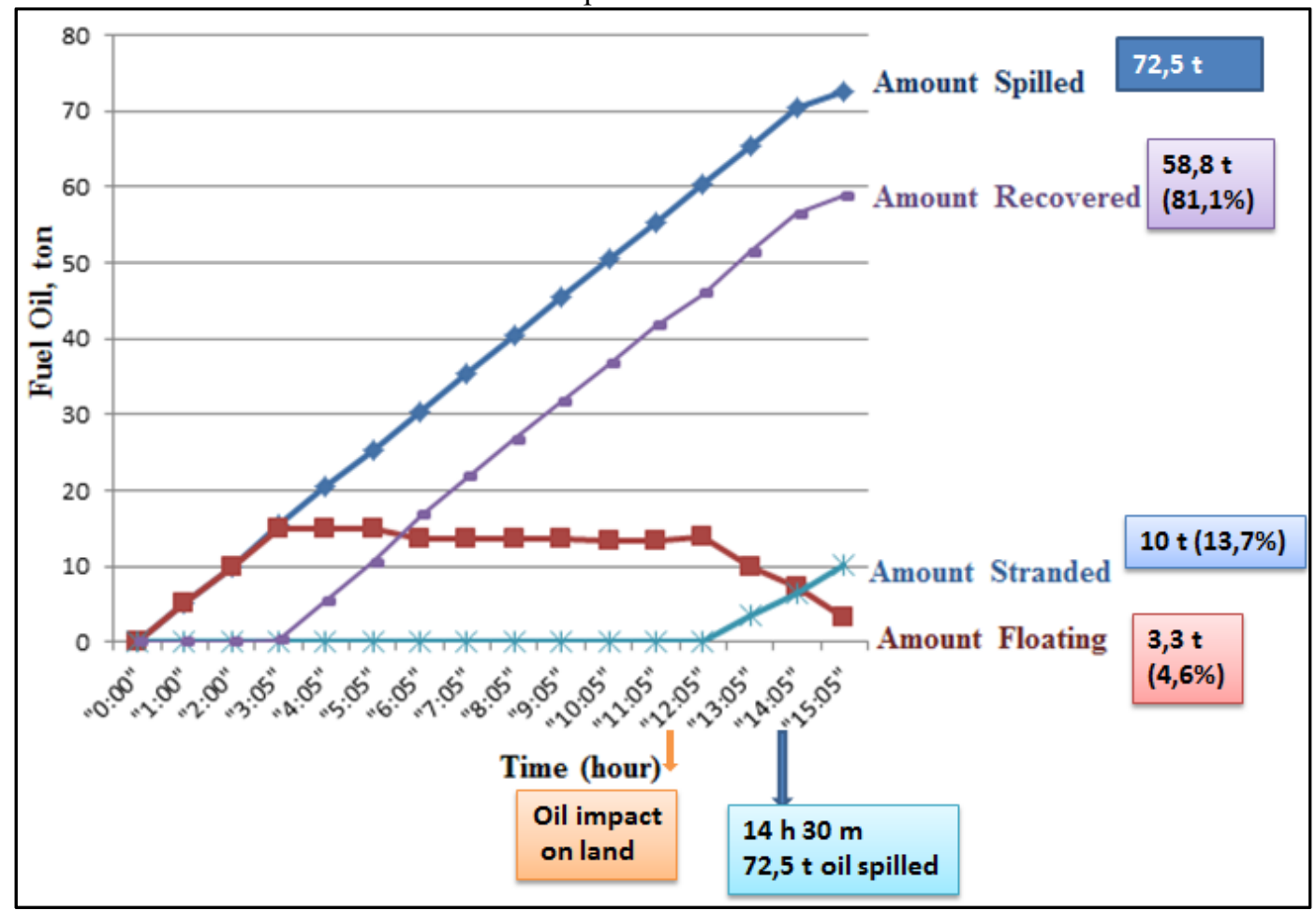

Figure 20. The Graphic of the Spill/Pollution Statistics of Scenario-2 by Creating the Response Operation.

\section{Results}

The following results were obtained by examining the reports about the accident and the news obtained from the press.

- Even if, the right after the accident, ship's Captain reported the pollution to the ship's agent that an immediate action/response was necessary, the response operation was started late following the accident. Therefore, the spilled oil amount from the ship increased the marine pollution.

- According to the accident investigation report on the grounding of M/V Lady Tuna, the response company started to encircle the ship with a barrier about $9 \mathrm{~h}$ after the oil leakage in order to control the pollution arising from the ship. On the other hand, according to the captain's statement from the court report, the insufficient boom (barrier) was encircled to the ship $11 \mathrm{~h}$ after the spillage. This situation shows that the differences and inconsistencies in the documents of the official institutions about when the response company started the operation to control pollution.

- The response company reached the accident region $7 \mathrm{~h}$ after the accident, but firstly they began to encircle the fish farms with barriers. About $9 \mathrm{~h}$ after the spillage, they began to encircle the ship around with a barrier (which is not efficient in high sea condition). However, first of all, they should have started the response operation against the leak source. As a statistics presented that $81,1 \%$ of the spilled oil (58.8 tons) was recovered when the oil spill response actions was taken without losing time. result, the response operation was delayed at least 2 h. This caused more than 10 tons of the fuel to spill.

- The response company "Most", which is based at Ulusoy Port, in the administrative responsibility area of Çeşme Port Authority was managed the response operation. Distance from the Ulusoy Çeşme Port to the accident position is about $12.00 \mathrm{NMs}$ by the sea. It is a distance that can be taken within one hour by the supply vessel loaded with response resources. However, the response company reached the accident region $7 \mathrm{~h}$ after the accident.

- According to the report, $9 \mathrm{~h}$ after the spillage, the ship was encircled with a boom as well as the two skimmers removed the floating oil from the point they were located. But, in $9 \mathrm{~h}, 45$ tons of fuel spilled into the sea and moved away from the ship towards the southwest direction due to the wind and the current in the region. At the end, the oil remained on the ship was only 27,5 tons. It means the response operation was focused on the remained oil. Therefore, 45 tons of spilled oil stranded towards the Ildir coast.

- On 24th December 2016 (6 days after the accident), the tanker ship discharged the fuel in her damaged tanks and discharging operation was completed on 26th December 2016. The weather report shows that the violent storm increased three days after the accident. It created a greater danger to the damaged ship and the environment. The discharge operation of the fuel on the ship normally should be made shortly after the accident. 
- As a result, many inconsistencies have been observed with regard to the response activities of the M/V Lady Tuna; these are deficiencies in the implementation of the response plans, inadequacy of the available response resources, delays in the collection and distribution of response resources as well as communication and coordination problems between institutions and authorities.

In the other phase of the study, the M/V Lady Tuna grounding accident was modelled with PISCES II and the following results are achieved:

- The trajectories of the spilled oil after accident showed that the oil spread under the effect of the SW wind direction and surface current on the sea.

- After $14 \mathrm{~h}$ and $30 \mathrm{~min}$. following the accident, 72.50 tons fuel oil leaked from the ship's tanks. Firstly, the oil stranded on the Paşalimanı coast (3.50 NMs far away from the accident) about $12 \mathrm{~h}$ later following the spillage. There is the nearest the coast towards SW the direction of the current and wind. And then, the oil slick continued to spread towards the Paşalimanı coast, the Boyalık Bay, the Setur Çeşme Marina, the Radisson Blue Resort Hotel beach, the Ilica Hotel beach, the Yildizburnu coast, Sherotan Hotel beach and the Ilica public beaches.

- The spill statistics revealed that the evaporation and dispersion oil amount were very low rate dependent upon the nature of the oil (IFO 180, the heavy fuel oil) as well as the moderate sea state. Therefore the most of the oil slick on the sea stranded towards the Ildir coast.

- The main objective of the response operation following the oil spill incident is not to allow the oil to reach the coastline where it creates the most destruction to the environment. Therefore, one open water boom and two Oleophilic skimmers were deployed around the leak source after $3 \mathrm{~h}$ from the spillage by one oilfield supply vessel. But, the spilled oil (about 15 tons) spread to seawater in three $h$ before the response resources deployed on the sea. So, the one $\mathrm{J}$ shape boom formation was deployed in the direction of the oil leak and moved with one Oleophilic skimmer towards the leakage source. The movement of the $\mathrm{J}$ shape boom formation was controlled by two oilfield supply vessels and it allowed the oil collecting by trawling.

- The simulation PISCES II showed a significant influence on the efficiency of oil spill recovery from the surface of the sea. The spill statistics revealed that $81.10 \%$ of the spilled oil (58.80 tons) was recovered and the stranded oil was limited to 10 tons after the response operation was managed without losing time. Thus, the spilled oil did not spread on the sea and cause less damage to the marine environment.

- Before the response operations are planned, the nature of the spilled oil, the effectiveness of the response resources and sea condition should be considered during the operation.

- So, the Oleophilic skimmers and Open Water Boom models were selected dependent upon the high viscosity of the spilled oil (IFO 180) and the sea state after the accident.

- In the case of early response to the oil spill following the accident; the response resources can be prepared by professional personnel within $1 \mathrm{~h}$ after the accident notice.

The response resources (the booms, the skimmers) can be reached the accident area by the supply vessels within one hour and the resources can be deployed on the sea within one hour. It means the response process can begin at the latest in $3 \mathrm{~h}$ under the ideal conditions.

\section{Conclusion}

Turkey should take more serious steps concerning with response operation and preparedness for eliminating oil pollution in emergency incidences. The officials and the response operation companies should also consider the following:

- Transparent coordination and communication should be between the organizations and officials.

- It is necessary to urgently assess the situations like the behavior of the oil on seawater, the shoreline area impacted by oil and response strategies to take early action to prevent oil pollution.

- The transfer operation of the remained oil in the ship and salvage operation of the ship should be conducted as soon as possible.

- The personnel involved in the response operation should be professional and trained.

- To avoid delays in collection and distributing sources of response, they must be properly checked to assess their suitability and performance.

- Nowadays, it is widely used to make approaches that utilize advanced technology detection systems and various models in relation to oil accidents. Autonomous decision support systems that are responsive to situational awareness and equipped with machine learning, which can respond faster in spatial analysis, will be used more intensely in environmental disasters such as oil pollution.

- The PISCES II and the other software programs are important for the coordinators managed the response operation. The simulation program has the most advantage of documenting pollution/spill statistics, the stranded oil amount to the shoreline, the time to oil reach the coast, efficiency rate of the response equipment.

\section{References}

Abdikan, S., Bayık, Ç., Balık Şanlı, F. (2018). The Role af Sar Remote Sensing To Detect Oil Pollution And Emergency Intervention, Ünlü, S., Alpar, B., Öztürk, B. (Eds) (2018). Oil Spill along the Turkish Straits Sea Area; Accidents, Environmental Pollution, SocioEconomic Impacts and Protection. Turkish Marine Research Foundation (TUDAV), Publication No: 47 İstanbul, Turkey, 157-175. 
AIB (Accident Investigation Board), (2017). Accident investigation report on the grounding of $M / V$ Lady Tuna. Ministry of Transport, Maritime Affairs and Communications: Accident Investigation Board, (32/DNZ-04/2017), Ankara, Turkey. Retrieved 28 April 2018, from http://www.kaik.gov.tr

Boufadel, M., Chen, B., Foght, J., Hodson, P., Lee, K., Swanson, S., Venosa, A. (2015). The behaviour and environmental impacts of crude oil released into aqueous environments, The Royal Society of Canada Expert Panel Report, Ottawa, Canada, November 2015. ISBN: 978-1-928140-02-3

CPN (Chart Plotter Navigation) (2018), Retrieved 20 December 2018, from https://opencpn.org/

Delvigne, G. A. L., Sweeney, C. E. (1988). Natural dispersion of oil. Oil and Chemical Pollution, 4(4), 281-310. Doi:10.1016/S0269-8579(88)80003-0

Doğan, E., C. Gazioğlu, E. Okuş, I.E. Gönenç, H. Yüce., ZY. Yücel. (1998). Examination of the Pollution in the West Black Sea by Remote Sensing Technologies, Journal of Black Sea/Mediterranean Environment, 4(2), 89-101.

Fay, J.A. (1969). The spread of oil slicks on a calm sea. In D. P. Hoult (Ed.), Oil on the Sea, 53-63. New York.

Fay, J.A. (1971). Physical processes in the spread of oil on a water surface. Proceedings of the Joint Conference on Prevention and Control of Oil Spills, American Petroleum Institute, Washington D. C., pp 463-467.

Fingas, M., Fieldhouse, B., Mullin, J. (1996). Studies of water-in-oil emulsions: the role of asphaltenes and resins, Proceedings of the Nineteenth Arctic and Marine Oil spill Program (AMOP) Technical Seminar, Environment Canada, Emergencies Science Division, Ottawa, Ontario, Canada.

Fingas, M.F. (2013). Modeling oil and petroleum evaporation, Journal of Petroleum Science Research, 2 (3), 104-115.

Gazioğlu, C. (2018). Biodiversity, coastal protection, promotion and applicability investigation of the ocean health index for Turkish seas. International Journal of Environment and Geoinformatics (IJEGEO). 5(3), 353-367.

Gazioğlu, C., Akkaya, M.A., Baltaoğlu, S., Burak, SZ. (2016). ICZM and the Sea of Marmara: The İstanbul Case. The Sea of Marmara: Marine Biodivesity, Fisheries, Conservations and Governanace (Editors: Özsoy, E., Çağatay, M.N., Balkıs, N., Balkıs Çağlar, N., Öztürk, B.), 935-957.

Gazioğlu, C., Ö.E. Varol, D.Z. Şeker,., N. Çağlar. (2017). Determination of the Environmental Impacts of Marine Accidents Using UAV and RS Technologies, 19th MESAEP Symposium on Environmental and Health Inequity, Roma, ITALYA, 3-6 Dec 2017.

Güven, K.C., E. Okuş, H.İ. Sur, C. Gazioglu, A. Yuksek, S. Ünlü, H. Altiok, S. Tas, A.E. Muftuoglu, N. Yilmaz, A. Aslan Yilmaz, U. Karhan., A. Yalcin (2006). Petroleum pollution of Volgoneft-248 tanker accident in the Florya- Küçükçekmece area. Final Report. Istanbul University, Institute of Marine Sciences and Management, Istanbul, Turkey.

Hault, D.P. (1972). Oil spreading on the sea, Annual Review of Fluid Mechanics, 4, pp. 341-368.
İstikbal, C., Erkan, N. (2018). A contemporary analysis on fish farms and the safety of navigation. Aquatic Research, 1(1), 18-25, DOI: 10.3153/AR18003

ITOPF (International Tanker Owners Federation), (2002). Fate of marine oil spills, Technical Information Paper, (2), Retrieved 05 July 2017 from http://www.itopf.com/knowledgeresources/documents -guides/document/tip-2-fate-of-marine-oil-spills/

Lehr, W.J., Fraga, R.J., Belen, M.S., Cekirge, H.M., (1984). A new technique to estimate initial spill size using a modified fay-type spreading formula. Marine Pollution Bulletin, 15 (9), 326-329.

Mackay, D., Buistt, I.A., Marcarenhas, R., Paterson, S. (1980). Oil spill processes and models. Environment Canada Manuscript Report No. EE-8, Ottawa, Ontario.

Meriç, E., Avşar, N., Nazik, A., Yokeş, B., Dora, Ö., Barut, İ. F., Eryılmaz, M., Dinçer, F., Kam, E., Aksu, A. ( (2012). The influences of oceanographical characteristics of the north coasts of karaburun peninsula on the benthic foraminiferal and os-tracod assemblages, Mineral Res. Exp., Bull., 145, 22-47.

MEVBIS (Turkish State Meteorological Service), (2017). Meteorological weather statistics of Çeşme/Izmir, Meteorological data information sales and presentation sytem, Ankara. The online from https://mevbis.mgm.gov.tr/mevbis/ui/index.html\#/Wo rkspace

Notification to the Emergency Response Firms (2017). Ministry of Transport, Maritime Affairs and Communications, General Directorate of Marine and Inland Water Regulatory Affairs, (Numbered: 36712415-160.03.02-E. 12358, Retrieved 09 Feb. 2017 from

http://www.ubak.gov.tr/BLSM_WIYS/DISGM/tr/doc/ $20180409153046 \quad 66968 \quad 1 \quad \overline{64} . p d f$

Papila, İ., Sertel, E., Kaya, Ş., Gazioğlu, C. (2018). Oil Spill Detection Using Remote Sensing TechnologiesSynthetic Aperture Radar (SAR), Ünlü, S., Alpar, B., Öztürk, B. (Eds) (2018). Oil Spill along the Turkish Straits Sea Area; Accidents, Environmental Pollution, Socio-Economic Impacts and Protection. Turkish Marine Research Foundation (TUDAV), Publication No: 47 İstanbul, Turkey, 140-156.

PISCES II Manual (2008). http://www.transas.com/

Seanews, (2017). Lady Tuna accident in çesme, Retrived 20 Oct. 2017 from https://www.seanews.com.tr/fotogaleri/lady-tuna-accident-in-cesme/3/resim/

Şeker, DZ., Direk, Ş., Musaoğlu, N., Gazioğlu, C. (2013). Determination of effects of coastal deformation caused by waves and storms at Black Sea coast of Turkey utilizing InSAR technique, $A G U$ Fall Meeting Abstracts

Soltanpour, M., Wijayaratna, N., Hajisalimi, Z. (2013). Numerical modeling of oil slick spread in the Persian Gulf. International Journal of Maritime Technology, 1 (1), 57-66.

Sunlu, U., Kayacan, B., Küçükgül, E.Y. (2017). The expert report of $M / V$ Lady Tuna accident, The Republic of Turkey Çeşme Civil Court of the First Instance, (No: 2017/1), Retrieved 28 January 2018, from http://www.turksail.com/attachments/article/15271/Ce sme\%20\%202017.1.pdf

Windguru, (2018). https://www.windguru.cz/ 